\title{
Epidermal Growth Factor Receptor Tyrosine Kinase Inhibitors in Advanced Non-Small Cell Lung Cancer
}

\author{
Prabhat Singh Malik $^{\mathrm{a}}$ Deepali Jain ${ }^{\mathrm{b}}$ Lalit Kumar ${ }^{\mathrm{a}}$ \\ ${ }^{a}$ Department of Medical Oncology, Dr. B.R.A. Institute Rotary Cancer Hospital, and ${ }^{\text {b }}$ Department of Pathology, \\ All India Institute of Medical Sciences, New Delhi, India
}

\section{Key Words}

Epidermal growth factor receptor mutation · Epidermal growth factor receptor tyrosine kinase inhibitors .

Personalized medicine - Pathological and molecular profile

\begin{abstract}
The advent of epidermal growth factor receptor (EGFR) tyrosine kinase inhibitors (TKIs) has led to a paradigm shift in the management of advanced adenocarcinoma of the lung. The key to success of these therapies lies in the precise identification of their molecular targets, i.e. sensitizing EGFR mutations. The variations in the prevalence of these mutations among different ethnicities necessitate regional studies for a better understanding of the molecular epidemiology of the disease and clinical decision-making. This is even more relevant for countries like India where genetic heterogeneity is a rule. Here, we make an attempt to review the epidemiology of EGFR mutations in India versus other Asian countries and the West. We also review the clinical experience with EGFR TKIs and suggest the way forward in a resource-limited setting.

(c) 2016 S. Karger AG, Basel
\end{abstract}

\section{KARGER}

(c) 2016 S. Karger AG, Basel

0030-2414/16/0917-0026\$39.50/0

E-Mail karger@karger.com

www.karger.com/ocl

\section{Introduction}

Lung cancer is the most common cancer among males and a major cause of cancer-related deaths all over the world. It accounts for $13 \%$ of all new cancer cases [1]. In India, lung cancer constitutes $6.9 \%$ of all new cancer cases and $9.3 \%$ of all cancer-related deaths in both sexes [1]. The prevalence pattern and pathological profile of the disease vary significantly among various ethnicities and geographic locations and largely reflect smoking pattern, genetic heterogeneity and possibly other environmental factors. During the past decade, with better understanding of molecular biology, newer targets and driver mutations have been identified. This has led to the development of novel epidermal growth factor receptor tyrosine kinase inhibitors (EGFR TKIs). These are currently being recommended in the treatment of advanced/metastatic disease in eligible patients. This is based on the results of a number of randomized, metacentric studies in a large number of patients. In this review, we make an attempt to summarize the available data from India on frequency and type of EGFR mutations, clinical experience with EGFR TKIs and its potential impact on outcome. 
Table 1. Pathological profile: Indian data

\begin{tabular}{|c|c|c|c|c|c|}
\hline Study & $\begin{array}{l}\text { Patients, } \\
\mathrm{n}\end{array}$ & $\begin{array}{l}\text { Median age, } \\
\text { years }\end{array}$ & $\begin{array}{l}\mathrm{M}: \mathrm{F} \\
\text { ratio }\end{array}$ & $\begin{array}{l}\text { Smoker:non-smoker } \\
\text { ratio }\end{array}$ & $\begin{array}{l}\text { Histological } \\
\text { characterization }\end{array}$ \\
\hline $\begin{array}{l}\text { Behera and } \\
\text { Balamugesh [8] }\end{array}$ & 1,009 & 54.3 & $4.5: 1$ & $2.7: 1$ & $\begin{array}{l}\text { Sq: } 34.3 \% \\
\text { Ade: } 25.9 \% \\
\text { Others: } 39.8 \%\end{array}$ \\
\hline Prasad et al. [12] & 400 & 57 & $4.3: 1$ & $2.5: 1$ & $\begin{array}{l}\text { Sq: } 46.5 \% \\
\text { Ade: } 18.2 \% \\
\text { Others: } 35.3 \%\end{array}$ \\
\hline Khan et al. [13] & 321 & & $11.3: 1$ & $7.6: 1$ & $\begin{array}{l}\text { Sq: } 77.3 \% \\
\text { Ade: } 5.3 \% \\
\text { Others: } 17.4 \%\end{array}$ \\
\hline Singh et al. [9] & 250 & 57.9 & $4.4: 1$ & $2.67: 1$ & $\begin{array}{l}\text { Sq: } 34.8 \% \\
\text { Ade: } 26 \% \\
\text { Others: } 18.4 \%\end{array}$ \\
\hline Noronha et al. [11] & 489 & 56 & $3.5: 1$ & 0.9:1 & $\begin{array}{l}\text { Sq: } 26.2 \% \\
\text { Ade: } 43.8 \% \\
\text { Others: } 30 \%\end{array}$ \\
\hline Malik et al. [10] & 434 & 55 & $4.6: 1$ & $2.1: 1$ & $\begin{array}{l}\text { Sq: } 29.4 \% \\
\text { Ade: } 45.41 \% \\
\text { Others: } 25.1 \%\end{array}$ \\
\hline
\end{tabular}

\section{Pathological Profile of Lung Cancer: The Changing Paradigm}

In recent years, the histological characterization of lung cancer has become important in view of genomic classification of lung carcinoma and histologically guided therapeutic intervention [2, 3]. In Europe, North Ameri$\mathrm{ca}$ and most of the Asian countries, the incidence of adenocarcinoma has already surpassed that of squamous cell carcinoma $[4,5]$. This shift has been attributed partly to the smoking pattern and increasing incidence of lung cancer in females and non-smokers $[4,6,7]$. This shift in histology subtype has also been observed in India. While the earlier and even a few recent hospital-based studies have described squamous cell carcinoma as the most common histology $[8,9]$, recent data from two major centers have shown a changing pattern, i.e. adenocarcinoma as the most common histological subtype, similar to the West $[10,11]$ (summarized in table 1). Many patients who were earlier classified as non-small cell carcinoma not otherwise specified (NSCLC NOS), can be further subclassified after careful review of the pathology with the appropriate use of immunohistochemistry. In a recent study, in an independent pathology review of 174 biopsy specimens, the histological subtype was changed in $24 \%$ of cases. [10].

\section{EGFR Mutations: Frequency}

The incidence of EGFR mutations varies among different ethnic and geographical populations. In Caucasian populations $10 \%$ of patients harbor these mutations, while in East Asian patients the frequency has been reported to be as high as $60 \%[14,15]$. In the Indian population, where there is genetic diversity, a frequency of $23-50 \%$ has been reported (table 2) [16-23]. The techniques of mutation testing as well as the type of referrals have varied in these studies. In a recent multinational study among patients with advanced adenocarcinoma of the lung from Asian countries, it was reported that the frequency of mutations in Indians is lower: 22.2 versus $47.2-67.2 \%$ compared to data of other Asian countries [24]. These differences highlight the importance of molecular epidemiology and the need for regional studies. 
Table 2. Frequency of EGFR mutations in Indian, Western and other Asian populations

\begin{tabular}{|c|c|c|c|c|c|}
\hline Study & Patients, $\mathrm{n}$ & Technique & $\begin{array}{l}\text { Prevalence } \\
\text { of mutations }\end{array}$ & Mutation subtypes & Ethnicity \\
\hline Sahoo et al. [16] & 220 & Scorpian ARMS PCR & $51.8 \%$ & $\begin{array}{l}\text { Exon 19: } 51.6 \% \\
\text { Exon } 21: 26.2 \% \\
\text { Exon 18: } 7.9 \% \\
\text { Exon 20: } 3.0 \%\end{array}$ & Indian \\
\hline Chougule et al. [18] & 907 & TaqMan PCR & $23.2 \%$ & $\begin{array}{l}\text { Exon 19: } 50 \% \\
\text { Exon 21: } 42 \% \\
\text { Exon 18: } 7 \% \\
\text { Exon 20: } 3 \%\end{array}$ & Indian \\
\hline Bhatt et al. [20] & 106 & Direct sequencing & $39.6 \%$ & $\begin{array}{l}\text { Exon 19: } 76.2 \% \\
\text { Exon } 21: 7 \% \\
\text { Exon 18: } 2.4 \% \\
\text { Exon } 20: 4.8 \%\end{array}$ & Indian \\
\hline Veldore et al. [21] & 1,036 & Scorpian ARMS PCR & $40.3 \%$ & $\begin{array}{l}\text { Exon 19: } 61 \% \\
\text { Exon } 21: 31.8 \% \\
\text { Exon 18: } 4.5 \% \\
\text { Exon 20: } 4 \%\end{array}$ & Indian \\
\hline Reinersman et al. [26] & 121 & PCR & $19 \%$ & $\begin{array}{l}\text { Exon 19: } 78.2 \% \\
\text { Exon } 21: 21.8 \%\end{array}$ & $\begin{array}{l}\text { African } \\
\text { American }\end{array}$ \\
\hline Douillard et al. [27] & 1,060 & Scorpian ARMS PCR & $14 \%$ & $\begin{array}{l}\text { Exon 19: } 65 \% \\
\text { Exon } 21: 31 \%\end{array}$ & Caucasian \\
\hline
\end{tabular}

ARMS = Amplification-refractory mutation system; PCR = polymerase chain reaction; RFPL = restriction fragment length polymorphism; IHC = immunohistochemistry.

\section{EGFR TKIs: Clinical Experience}

Protein kinases are attractive therapeutic targets for cancer cells because of frequent dysregulation. Small molecules like gefitinib and erlotinib are the first-generation TKIs of EGFR, which blocks binding of adenosine- $5^{\prime}$ triphosphate (ATP) to the tyrosine kinase catalytic do- main and thereby inhibits the downstream signaling. In 2004, three groups of researchers identified that the subgroup of NSCLC tumors which harbored a mutation in the EGFR gene, detected by direct sequencing, were highly sensitive to EGFR TKIs [28-30]. Although the initial clinical experience of EGFR TKIs was analyzed in an unselected patient population and later on in a clinically se- 
lected population (Asian ethnicity, non-smoker, female gender and adenocarcinoma histology), nowadays, the clinical efficacy of these drugs is usually indicated by the molecular selection. Table 3 summarizes the major clinical studies on EGFR TKIs.

\section{Unselected Population}

ISEL (Iressa Survival Evaluation in advanced Lung cancer) is a large phase III study in which gefitinib was compared with placebo in patients who were refractory or intolerant to chemotherapy [31]. Here, gefitinib did not improve the survival as compared to placebo; however, there was some evidence of a benefit among neversmokers and patients of Asian origin. In a retrospective ad hoc analysis of 77 Indian patients included in the ISEL study, the median survival was observed to be 6.4 months with gefitinib and 5.1 months with placebo. The response rates were also better with gefitinib (14 vs. 0\%) [32].

Another randomized phase III study (INTEREST) compared gefitinib with docetaxel in 1,433 previously treated NSCLC patients [33]. This study endorsed the non-inferiority of gefitinib to docetaxel in a second-line setting. On the other hand, in a Japanese study (V-15-32) gefitinib was compared with docetaxel in 489 patients with advanced NSCLC who had failed one or two lines of therapy [34]. However, this study could not demonstrate a non-inferiority of gefitinib in terms of overall survival (OS) (primary endpoint) according to predefined criteria, but there was no statistically significant difference in OS. Gefitinib fared better compared to docetaxel in terms of tumor response and improvement in quality of life.

In the BR.21 study, erlotinib was compared with placebo in previously treated NSCLC patients and was found to be superior in terms of progression-free survival (PFS) (2.2 vs. 1.8 months) and median survival time (6.7 vs. 4.7 months) [35]. Another phase III trial, TITAN, compared erlotinib with second-line chemotherapy (docetaxel or pemetrexed) for previously treated patients with advanced NSCLC and showed a similar OS (5.3 vs. 5.5 months) [36].

\section{Clinically Selected Population}

In a preplanned subgroup analysis of the ISEL study, gefitinib was shown to improve survival in patients of Asian origin and in non-smokers [37]. Therefore in 2006, the Iressa ${ }^{\circledR}$ Pan-Asia Study (IPASS) was initiated to investigate the effectiveness of first-line gefitinib in previously untreated patients in East Asia who had advanced pulmonary adenocarcinoma and who were light smokers or non-smokers [38]. In this study, 1,217 patients from Asian countries were randomized to receive gefitinib 250 mg or a combination of carboplatin and paclitaxel. The study met its primary endpoint of non-inferiority of gefitinib as compared to chemotherapy in terms of PFS. The PFS at 12 months was $24.9 \%$ with gefitinib and $6.7 \%$ with chemotherapy. However, a subgroup of 261 patients with EGFR mutations (detected by ARMS PCR) had a significant PFS benefit with gefitinib. On the other hand, in 176 patients with mutation-negative disease, gefitinib was associated with an inferior outcome as compared to chemotherapy [38].

\section{Selection by EGFR Mutation}

In March 2006, at the same time when the IPASS study was started, two other phase III trials, the North East Japan (NEJ) 002 study [39] and the West Japan Thoracic Oncology Group (WJTOG) 3405 [40], were initiated, which compared gefitinib with standard chemotherapy in first-line treatment for EGFR-mutated NSCLC. NEJ 002 confirmed as the primary endpoint that PFS was significantly longer in the gefitinib group than in the carboplatin plus paclitaxel group [ 10.8 vs. 5.4 months; hazard ratio (HR) $0.30, \mathrm{p}<0.001]$. The WTOJ 3405 study also demonstrated a superior PFS with gefitinib as compared to cisplatin plus docetaxel (9.2 vs. 6.3 months; HR 0.489, $\mathrm{p}<0.0001)$.

Similarly, erlotinib was evaluated in a phase III trial (OPTIMAL) of Chinese patients with advanced NSCLC with an EGFR mutation. Erlotinib was associated with significantly better PFS compared to gemcitabine plus carboplatin (13.1 vs. 4.6 months; HR 0.16, p < 0.0001) [41]. Another phase III study (EURTAC) compared erlotinib to the standard chemotherapy in European patients with advanced NSCLC [42]. Erlotinib resulted in significantly better PFS as compared to the standard chemotherapy ( 9.7 vs. 4.2 months; HR 0.37 , p < 0.0001) [42].

Afatinib, an irreversible and more potent TKI, has also been evaluated in mutation-positive patients. It was found to improve PFS as compared to chemotherapy (LUX-Lung 3 and LUX-Lung 6) [43, 44].

Oncology 2016;91(suppl 1):26-34 DOI: $10.1159 / 000447578$ 
Table 3. Major clinical studies on EGFR TKIs

\begin{tabular}{|c|c|c|c|c|c|c|}
\hline Study & Study population & $\begin{array}{l}\text { Patients, } \mathrm{n} \\
\text { (M:F) }\end{array}$ & $\begin{array}{l}\text { Drug and } \\
\text { comparison arm }\end{array}$ & Response rates & PFS & OS \\
\hline ISEL [31] & $\begin{array}{l}\text { Unselected patients } \\
\text { who progressed or were } \\
\text { intolerant after } \\
\text { chemotherapy }\end{array}$ & $\begin{array}{l}1,692 \\
(1,129: 563)\end{array}$ & $\begin{array}{l}\text { Gefitinib vs. } \\
\text { placebo }\end{array}$ & - & - & $\begin{array}{l}5.6 \text { vs. } 5.1 \text { months } \\
\text { HR } 0.89 \\
(95 \% \text { CI } 0.77-1.02)\end{array}$ \\
\hline $\begin{array}{l}\text { INTEREST } \\
{[33]}\end{array}$ & $\begin{array}{l}\text { Unselected patients } \\
\text { previously treated with } \\
\text { platinum-based } \\
\text { chemotherapy }\end{array}$ & $\begin{array}{l}1,433 \\
(723: 710)\end{array}$ & $\begin{array}{l}\text { Gefitinib vs. } \\
\text { docetaxel }\end{array}$ & - & - & $\begin{array}{l}7.6 \text { vs. } 8 \text { months } \\
\text { HR } 1.02 \\
(96 \% \text { CI } 0.905-1.150)\end{array}$ \\
\hline V-15-32 [34] & $\begin{array}{l}\text { Unselected patients } \\
\text { who failed one or more } \\
\text { lines of chemotherapy }\end{array}$ & $\begin{array}{l}490 \\
(245: 244) \\
1 \text { patient } \\
\text { excluded }\end{array}$ & $\begin{array}{l}\text { Gefitinib vs. } \\
\text { docetaxel }\end{array}$ & $\begin{array}{l}22.5 \text { vs. } 12.8 \% \\
(p=0.009)\end{array}$ & $\begin{array}{l}2 \text { vs. } 2 \text { months } \\
\text { HR } 0.90 \\
(95 \% \text { CI } 0.72-1.12)\end{array}$ & $\begin{array}{l}11.5 \text { vs. } 14 \text { months } \\
\text { HR } 1.12 \\
(95.24 \% \text { CI } 0.89-1.40)\end{array}$ \\
\hline BR.21 [35] & $\begin{array}{l}\text { Unselected patients } \\
\text { who failed one or two } \\
\text { lines of chemotherapy }\end{array}$ & $\begin{array}{l}731 \\
(488: 243)\end{array}$ & $\begin{array}{l}\text { Erlotinib vs. } \\
\text { placebo }\end{array}$ & $\begin{array}{l}8.9 \text { vs. }<1 \% \\
(p<0.001)\end{array}$ & $\begin{array}{l}2.2 \text { vs. } 1.8 \text { months } \\
\text { HR } 0.61 \\
(95 \% \text { CI } 0.51-0.74)\end{array}$ & $\begin{array}{l}6.7 \text { vs. } 4.7 \text { months } \\
\text { HR } 0.70 \\
(95 \% \text { CI } 0.58-0.85)\end{array}$ \\
\hline TITAN [36] & $\begin{array}{l}\text { Unselected patients } \\
\text { who progressed after } \\
\text { platinum-based doublet } \\
\text { chemotherapy }\end{array}$ & $\begin{array}{l}424 \\
(203: 221)\end{array}$ & $\begin{array}{l}\text { Erlotinib vs. } \\
\text { pemetrexed or } \\
\text { docetaxel }\end{array}$ & $\begin{array}{l}34.5 \text { vs. } 43 \% \\
(p=0.073), \text { disease } \\
\text { control rate }\end{array}$ & $\begin{array}{l}6.3 \text { vs. } 8.6 \text { weeks } \\
\text { HR } 1.19 \\
(95 \% \text { CI } 0.97-1.46)\end{array}$ & $\begin{array}{l}5.3 \text { vs. } 5.5 \text { months } \\
\text { HR } 0.96 \\
(95 \% \text { CI } 0.78-1.19)\end{array}$ \\
\hline IPASS [38] & $\begin{array}{l}\text { Clinically selected } \\
\text { (adenocarcinoma, } \\
\text { Asians, former light } \\
\text { smokers or } \\
\text { non-smokers) } \\
\text { treatment-naïve } \\
\text { patients }\end{array}$ & $\begin{array}{l}1,217 \\
(609: 608)\end{array}$ & $\begin{array}{l}\text { Gefitinib vs. } \\
\text { paclitaxel } \\
\text { carboplatin }\end{array}$ & $\begin{array}{l}43 \text { vs. } 32.2 \% \\
(p<0.001) \text { in } \\
\text { overall population, } \\
71.2 \text { vs. } 47.3 \% \text { in } \\
\text { EGFR mutation- } \\
\text { positive patients }\end{array}$ & $\begin{array}{l}5.7 \text { vs. } 5.8 \text { months } \\
\text { HR } 0.74(95 \% \text { CI } \\
0.65-0.85) \text { in overall } \\
\text { population } \\
9.5 \text { vs. } 6.3 \text { months } \\
\text { HR } 0.48 \text { (95\% CI } \\
0.36-0.64) \text { in EGFR } \\
\text { mutated patients }\end{array}$ & $\begin{array}{l}18.6 \text { vs. } 17.3 \text { months } \\
\text { HR } 0.91 \\
(95 \% \text { CI } 0.76-1.10)\end{array}$ \\
\hline NEJ 002 [39] & $\begin{array}{l}\text { EGFR-mutated } \\
\text { treatment-naïve } \\
\text { patients }\end{array}$ & $\begin{array}{l}230 \\
(115: 115)\end{array}$ & $\begin{array}{l}\text { Gefitinib vs. } \\
\text { paclitaxel } \\
\text { carboplatin }\end{array}$ & $\begin{array}{l}73.7 \text { vs. } 30.7 \% \\
(p<0.001)\end{array}$ & $\begin{array}{l}10.4 \text { vs. } 5.5 \text { months } \\
\text { HR } 0.36 \\
(95 \% \text { CI } 0.25-0.51)\end{array}$ & $\begin{array}{l}30.5 \text { vs } 23.6 \text { months } \\
(p=0.31)\end{array}$ \\
\hline $\begin{array}{l}\text { WJTOG } 3405 \\
{[40]}\end{array}$ & $\begin{array}{l}\text { EGFR-mutated } \\
\text { treatment-naïve } \\
\text { patients }\end{array}$ & $\begin{array}{l}177 \\
(88: 89)\end{array}$ & $\begin{array}{l}\text { Gefitinib vs. } \\
\text { docetaxel } \\
\text { cisplatin }\end{array}$ & $\begin{array}{l}62.1 \text { vs. } 32.2 \% \\
(p<0.0001)\end{array}$ & $\begin{array}{l}9.2 \text { vs. } 6.3 \text { months } \\
\text { HR } 0.489 \\
(95 \% \text { CI } 0.336-0.71)\end{array}$ & $\begin{array}{l}30.9 \text { months vs. NR } \\
\text { HR } 1.638 \\
(95 \% \text { CI } 0.75-3.58)\end{array}$ \\
\hline $\begin{array}{l}\text { OPTIMAL } \\
{[41]}\end{array}$ & $\begin{array}{l}\text { EGFR-mutated } \\
\text { treatment-naïve } \\
\text { patients }\end{array}$ & $\begin{array}{l}165 \\
(83: 82)\end{array}$ & $\begin{array}{l}\text { Erlotinib vs. } \\
\text { Gemcitabine } \\
\text { Carboplatin }\end{array}$ & $\begin{array}{l}83 \text { vs. } 36 \% \\
(p<0.0001)\end{array}$ & $\begin{array}{l}13.1 \text { vs. } 4.6 \text { months } \\
\text { HR } 0.16 \\
(95 \% \text { CI } 0.10-0.26)\end{array}$ & Data not mature \\
\hline $\begin{array}{l}\text { EURTAC } \\
{[42]}\end{array}$ & $\begin{array}{l}\text { EGFR-mutated } \\
\text { treatment-naïve } \\
\text { patients }\end{array}$ & $\begin{array}{l}173 \\
(86: 87)\end{array}$ & $\begin{array}{l}\text { Erlotinib vs. } \\
\text { cisplatin and } \\
\text { docetaxel or } \\
\text { gemcitabine }\end{array}$ & $\begin{array}{l}64 \text { vs. } 18 \% \\
(p<0.0001)\end{array}$ & $\begin{array}{l}9.7 \text { vs. } 4.2 \text { months } \\
\text { HR } 0.37 \\
(95 \% \text { CI } 0.25-0.54)\end{array}$ & $\begin{array}{l}19.3 \text { vs. } 19.5 \text { months } \\
\text { HR } 1.04 \\
(95 \% \text { CI } 0.65-1.68)\end{array}$ \\
\hline $\begin{array}{l}\text { LUX-Lung } 3 \\
\text { [43] }\end{array}$ & $\begin{array}{l}\text { EGFR-mutated } \\
\text { treatment-naïve } \\
\text { patients }\end{array}$ & $\begin{array}{l}345 \\
(230: 115)\end{array}$ & $\begin{array}{l}\text { Afatinib vs. } \\
\text { pemetrexed } \\
\text { Cisplatin }\end{array}$ & $\begin{array}{l}56 \text { vs. } 23 \% \\
(p=0.01)\end{array}$ & $\begin{array}{l}11.1 \text { vs. } 6.9 \text { months } \\
\text { HR } 0.58 \\
(95 \% \text { CI } 0.43-0.78)\end{array}$ & Median NR \\
\hline $\begin{array}{l}\text { LUX-Lung } 6 \\
\text { [44] }\end{array}$ & $\begin{array}{l}\text { EGFR-mutated } \\
\text { treatment-naïve } \\
\text { patients }\end{array}$ & $\begin{array}{l}364 \\
(242: 122)\end{array}$ & $\begin{array}{l}\text { Afatinib vs. } \\
\text { gemcitabine } \\
\text { cisplatin }\end{array}$ & $\begin{array}{l}66.9 \text { vs. } 23 \% \\
(p<0.0001)\end{array}$ & $\begin{array}{l}11.0 \text { vs. } 5.6 \text { months } \\
\text { HR } 0.28 \\
(95 \% \text { CI } 0.20-0.39)\end{array}$ & $\begin{array}{l}22.1 \text { vs. } 22.2 \text { months } \\
\text { HR } 0.95 \\
(95 \% \text { CI } 0.68-1.33)\end{array}$ \\
\hline
\end{tabular}




\section{EGFR TKIs in Patients with Poor Performance Status and Advanced Age}

Patients with poor performance status (PS; ECOG PS $>2$ ), as a group, are mostly unsuitable for chemotherapy and have been under-represented in clinical trials. TKIs offer a safer option for this group of patients. TOPICAL was a phase III double-blind randomized study conducted in the UK and tested erlotinib against placebo for patients with advanced NSCLC and poor PS who were unsuitable for chemotherapy [45]. OS did not differ between the erlotinib and placebo groups, but patients who developed a skin rash after 1 month of therapy had a significantly better survival with erlotinib (HR 0.76, p = 0.0058).

Another multi-center phase II NEJ 001 study has investigated the efficacy and feasibility of gefitinib treatment for advanced NSCLC patients harboring EGFR mutations but who were ineligible for chemotherapy due to poor PS [46]. The overall response rate was $66 \%$, and the median PFS and median survival time were 6.5 and 17.8 months, respectively. The PS improvement rate was $79 \%$ ( $\mathrm{p}<0.00005)$; in particular, $68 \%$ of the 22 patients improved the PS from $\geq 3$ to 0 or 1 .

The Tarceva Lung cancer Survival Treatment (TRUST) was an open-label phase IV study of unselected patients with advanced NSCLC [47]. In a subpopulation of elderly patients ( $\geq 70$ years) receiving first-line erlotinib $(\mathrm{n}=$ 485 ) in TRUST, the disease control rate was $79 \%$, median PFS was 4.57 months, and OS was 7.29 months.

Thus, in a mutation-enriched population like ours, offering TKIs upfront to this poor-risk subgroup along with best supportive care seems to be a reasonable option. Incorporation of clinical predictors like non-smoker, female sex, adenocarcinoma histology and development of rash in the therapeutic decision-making might be further helpful in such difficult situations.

\section{EGFR TKIs as Maintenance after Response to First-Line Chemotherapy}

Maintenance treatment after platinum-based doublet chemotherapy has been gaining a place in the management of advanced NSCLC in recent years. Two paradigms, continuation or switch maintenance, have emerged in this context. SATURN was a phase III randomized trial comparing maintenance treatment with erlotinib versus placebo in unselected patients with advanced NSCLC who had non-progressive disease after first-line chemotherapy [48]. Maintenance erlotinib was associated with an improvement in PFS (HR 0.71, p < 0.0001 ) and OS (HR 0.81, p = 0.01). The benefit was demonstrated in both the mutation-positive and overall population. Along with these two studies from Asia, WJTOG0203 and INFROM using gefitinib as maintenance demonstrated a benefit in terms of PFS $[49,50]$. However, the subgroup analysis of both SATURN and INFROM shows that the maximum benefit is gained by mutation-positive patients and further reinforces the utility of predictive biomarkers in deciding treatment. Since all these studies included unselected patients irrespective of mutation status and still demonstrated a benefit, it is acceptable to use maintenance TKIs, more so in a mutation-enriched population like ours.

\section{Experience from India}

There are very few studies on the use of TKIs from India. Parikh et al. [32] analyzed 77 Indian patients enrolled in the ISEL study. The median survival and objective response rates in Indian patients were better with gefitinib compared to placebo (6.4 vs. 5.1 months; 14 vs. $0 \%$ ). The tolerance among Indians was no different. Louis et al. [51] reported their experience of first-line use of gefitinib in 47 clinically selected patients from southern India and compared their outcome with 73 patients who were treated with chemotherapy at the same time. They reported a better PFS in the gefitinib group compared to chemotherapy ( 10 vs. 4 months; $\mathrm{p}=0.014$ ) despite the fact that there were more patients with poor PS and higher stage (stage 4) in the gefitinib group.

Noronha et al. [19] retrospectively analyzed 111 patients who were treated with EGFR TKIs. They performed EGFR mutation testing in these patients and found that 39 of 111 had evidence of mutation. The response rate was $74 \%$ in patients with activating mutation compared to $5 \%$ in mutation-negative patients. Median PFS was 10 versus 2 months and median OS was 19 versus 13 months in mutation-positive and -negative patients, respectively.

In our experience (unpubl. data), in 50 patients treated between 2008 and 2011, TKIs were used as upfront treatment based on clinical parameters, and the clinical benefit rate (complete, partial and stable response) was $54 \%$. The majority of patients in this cohort (80\%) had a poor PS (ECOG PS $\geq 2$ ). Median PFS and OS in this poor-risk population were 7.5 and 12.7 months, respectively. The decision of TKI use was mostly based on clin- 
ical parameters: $62 \%$ of patients were females, $72 \%$ nonsmokers and $82 \%$ had adenocarcinoma and bronchoalveolar histology. EGFR mutation results were available in 7 patients only, and 3 of them had a sensitizing mutation.

\section{Post-TKI Progression}

\section{Secondary Resistance}

Despite good initial response, almost all patients treated with EGFR TKIs have disease progression due to the development of secondary resistance. For more than $60 \%$ of cases, a plausible mechanism of resistance has been identified [52]. A second-site EGFR mutation, particularly T790M, is the most common mechanism of acquired resistance accounting for almost $50 \%$ of cases. The T790M substitution alters proper binding of the drug to the ATP pocket of EGFR and/or restores the affinity for ATP versus the drug back to the level of wild-type EGFR [53]. Another 5-10\% of cases demonstrate MET amplification [53]. A development of new mutations in the downstream signaling pathway like PIK3CA (5\%) and BRAF (1\%) is less frequently observed [54]. Rarely, a histological change to small cell carcinoma or epithelial to mesenchymal transition can be observed [54].

In recently published phase I-II trials, two third-generation TKIs (AZD9291 and rociletinib) have been demonstrated to be highly active in patients with a T790M mutation and showed impressive response rates of 61 and $59 \%$, respectively [55-56]. Several specific combinations directed against the genetic makeup of individual tumors are currently under evaluation (e.g. adding a MET inhibitor for tumors displaying no EGFR T790M but MET amplification, or adding a PI3K inhibitor for tumors displaying a secondary PI3KCA mutation, and so on).

Continuation of EGFR TKI beyond disease progression is a controversial issue. In a phase II study (ASPIRATION), continuation of erlotinib beyond progression was feasible, if patients had slow progressive disease ( $>6$ months of partial response/stable disease), asymptomatic minimal progressive disease, or new brain metastasis controlled locally [57]. However, on the other hand, the IMPRESS trial found no benefit for continuing treatment with gefitinib plus chemotherapy versus chemotherapy alone in patients with EGFR-mutated NSCLC who had disease progression on treatment with gefitinib. Progression was defined according to the RECIST criteria in the IMPRESS trial, and not by clinical symptoms or metastatic spread [58].

\section{Personalized Medicine in a Resource-Limited Setting: Challenges and the Way Forward}

In this new era, the validation of targeted therapeutic compounds should be paralleled to the development of predictive biomarkers. In order to address that, well-accessible centralized laboratories can generate quality epidemiological data as well as support policies of incorporation of high-cost targeted drugs in clinical practice.

Presently, most of the molecular testing facilities in India are in the private sector. The accessibility of such testing is limited for the majority of the Indian population due to the high cost. In addition, poor or lack of quality control and standardization among various laboratories are other issues. Such facilities are limited to the government sector or teaching institutions. These problems can be overcome by establishing centralized laboratories where standardized uniform techniques can be used. A bulk use of technique may reduce the cost of individual tests. Implementation of quality control policies and their scrutiny would also be easier and more practical in such centralized facilities. Use of techniques like dHPLC (denaturing high-performance liquid chromatography), HRMA (high-resolution melting analysis) and immunohistochemistry (using mutation-specific antibodies) as a screening procedure before whole-exon sequencing can reduce the cost and the turnaround time [59].

The availability of a generic version of TKIs has made these drugs easily accessible to larger number of patients. A better understanding of the molecular biology of NSCLC and EGFR mutation would be helpful to develop guidelines on the use of TKIs and therapy duration. In situations where mutation testing facilities are not readily available or accessible, TKIs should be used judiciously based on clinical judgment. In patients with advanced NSCLC and good PS, TKIs can be used as maintenance or second-line treatment after platinum-based doublet chemotherapy. The upfront treatment use of TKIs should be restricted to EGFR-mutated patients only. On the other hand, in patients who are not suitable candidates for cytotoxic chemotherapy because of poor PS, advanced age or comorbidities, TKIs may be a reasonable option. In such situations, clinical predictors like female sex, non-smoker, adenocarcinoma histology and development of rash after treatment can be used in the therapeutic decision-making.

\section{Disclosure Statement}

The authors declare no conflicts of interest.
Malik/Jain/Kumar 


\section{References}

1 Ferlay J, Soerjomataram I, Ervik M, Dikshit R, Eser S, Mathers C, et al: GLOBOCAN 2012 v1.0. Cancer Incidence and Mortality Worldwide: IARC Cancer Base No. 11. Lyon, IARC, 2013. http://globocan.iarc.fr (accessed May 2015).

2 Scagliotti G, Brodowicz T, Shepherd FA, Zielinski C, Vansteenkiste J, Manegold C, et al: Treatment-by-histology interaction analyses in three phase III trials show superiority of pemetrexed in nonsquamous non-small cell lung cancer. J Thorac Oncol 2011;6:64-70.

3 Standfield L, Weston AR, Barraclough H, Van Kooten M, Pavlakis N: Histology as a treatment effect modifier in advanced non-small cell lung cancer: a systematic review of the evidence. Respirology 2011;16:1210-1220.

4 Valaitis J, Warren S, Gamble D: Increasing incidence of adenocarcinoma of the lung. Cancer 1981;47:1042-1046.

5 Janssen-Heijnen MLG, Coebergh J-WW: The changing epidemiology of lung cancer in Europe. Lung Cancer 2003;41:245-258.

6 Thun MJ, Henley SJ, Burns D, Jemal A, Shanks TG, Calle EE: Lung cancer death rates in lifelong nonsmokers. J Natl Cancer Inst 2006;98:691-699.

7 Wakelee HA, Chang ET, Gomez SL, Keegan TH, Feskanich D, Clarke CA, et al: Lung cancer incidence in never smokers. J Clin Oncol 2007;25:472-478.

8 Behera D, Balamugesh T: Lung cancer in India. Indian J Chest Dis Allied Sci 2004;46: 269-281.

9 Singh N, Aggarwal AN, Gupta D, Behera D, Jindal SK: Unchanging clinico-epidemiological profile of lung cancer in north India over three decades. Cancer Epidemiol 2010;34: 101-104.

10 Malik PS, Sharma MC, Mohanti BK, Shukla NK, Deo S, Mohan A, et al: Clinico-pathological profile of lung cancer at AIIMS: a changing paradigm in India. Asian Pac J Cancer Prev 2013;14:489-494.

11 Noronha V, Dikshit R, Raut N, Joshi A, Pramesh CS, George K, et al: Epidemiology of lung cancer in India: focus on the differences between non-smokers and smokers: a singlecentre experience. Indian J Cancer 2012;49: 74-81.

12 Prasad R, James P, Kesarwani V, Gupta R, Pant MC, Chaturvedi A, et al: Clinicopathological study of bronchogenic carcinoma. Respirology 2004;9:557-560.

13 Khan NA, Afroz F, Lone MM, Teli MA, Muzaffar M, Jan N: Profile of lung cancer in Kashmir, India: a five-year study. Indian J Chest Dis Allied Sci 2006;48:187-190.

14 Sharma SV, Bell DW, Settleman J, Haber DA: Epidermal growth factor receptor mutations in lung cancer. Nat Rev Cancer 2007;7:169181.

15 Shi Y, Au JS-K, Thongprasert S, Srinivasan S, Tsai C-M, Khoa MT, et al: A prospective, molecular epidemiology study of EGFR muta- tions in Asian patients with advanced nonsmall-cell lung cancer of adenocarcinoma histology (PIONEER). J Thorac Oncol 2014;9: 154-162.

16 Sahoo R, Harini VV, Babu VC, Patil Okaly GV, Rao S, Nargund A, et al: Screening for EGFR mutations in lung cancer, a report from India. Lung Cancer 2011;73:316-319.

17 Doval DC, Azam S, Batra U, Choudhury KD, Talwar V, Gupta SK, et al: Epidermal growth factor receptor mutation in lung adenocarcinoma in India: a single center study. J Carcinog 2013;12:12.

18 Chougule A, Prabhash K, Noronha V, Joshi A, Thavamani A, Chandrani P, et al: Frequency of EGFR mutations in 907 lung adenocarcinoma patients of Indian ethnicity. PLoS One 2013;8:e76164.

19 Noronha V, Prabhash K, Thavamani A, Chougule A, Purandare N, Joshi A, et al: EGFR mutations in Indian lung cancer patients: clinical correlation and outcome to EGFR targeted therapy. PLoS One 2013;8:e61561.

20 Bhatt AD, Pai R, Rebekah G, Nehru GA, Dhananjayan S, Samuel A, et al: Clinicopathologic features of non-small cell lung cancer in India and correlation with epidermal growth factor receptor mutational status. Indian J Cancer 2013;50:94-101.

21 Veldore VH, Rao RM, Kakara S, Pattanayak S, Tejaswi R, Sahoo R, et al: Epidermal growth factor receptor mutation in non-small-cell lung carcinomas: a retrospective analysis of 1,036 lung cancer specimens from a network of tertiary cancer care centers in India. Indian J Cancer 2013;50:87-93.

22 Mehta J: Molecular epidemiology of epidermal growth factor receptor mutations in lung cancers in Indian population. Indian J Cancer 2013;50:102-106.

23 Jain D, Iqbal S, Walia R, Malik P, Cyriac S, Mathur SR, et al: Evaluation of epidermal growth factor receptor mutations based on mutation specific immunohistochemistry in non-small cell lung cancer: a preliminary study. Indian J Med Res 2016;143:308-314.

24 Shi Y, Au JS-K, Thongprasert S, Srinivasan S, Tsai C-M, Khoa MT, et al: A prospective, molecular epidemiology study of EGFR mutations in Asian patients with advanced nonsmall-cell lung cancer of adenocarcinoma histology (PIONEER). J Thorac Oncol 2014;9: 154-162.

25 Dogan S, Shen R, Ang DC, Johnson ML, D’Angelo SP, Paik PK, et al: Molecular epidemiology of EGFR and KRAS mutations in 3,026 lung adenocarcinomas: higher susceptibility of women to smoking-related KRASmutant cancers. Clin Cancer Res 2012;18: 6169-6177.

26 Reinersman JM, Johnson ML, Riely GJ, Chitale DA, Nicastri AD, Soff GA, et al: Frequency of EGFR and KRAS mutations in lung adenocarcinomas in African Americans. J Thorac Oncol 2011;6:28-31.
27 Douillard J-Y, Ostoros G, Cobo M, Ciuleanu T, McCormack R, Webster A, et al: First-line gefitinib in Caucasian EGFR mutation-positive NSCLC patients: a phase-IV, open-label, single-arm study. Br J Cancer 2014;110:5562.

28 Lynch TJ, Bell DW, Sordella R, Gurubhagavatula $S$, Okimoto $R A$, Brannigan $B W$, et al: Activating mutations in the epidermal growth factor receptor underlying responsiveness of non-small-cell lung cancer to gefitinib. N Engl J Med 2004;350:2129-2139.

29 Pao W, Miller V, Zakowski M, Doherty J, Politi K, Sarkaria I, et al: EGF receptor gene mutations are common in lung cancers from 'never smokers' and are associated with sensitivity of tumors to gefitinib and erlotinib. Proc Natl Acad Sci 2004;101:13306-13311.

30 Paez JG, Jänne PA, Lee JC, Tracy S, Greulich $\mathrm{H}$, Gabriel S, et al: EGFR mutations in lung cancer: correlation with clinical response to gefitinib therapy. Science 2004;304:14971500.

31 Thatcher N, Chang A, Parikh P, Rodrigues Pereira J, Ciuleanu T, von Pawel J, et al: Gefitinib plus best supportive care in previously treated patients with refractory advanced non-small-cell lung cancer: results from a randomised, placebo-controlled, multicentre study (Iressa Survival Evaluation in Lung Cancer). Lancet 2005;366:1527-1537.

32 Parikh P, Chang AY-C, Nag S, Digumarti R, Bhattacharyya GS, Doval DC, et al: Clinical experience with gefitinib in Indian patients. J Thorac Oncol 2008;3:380-385.

33 Kim ES, Hirsh V, Mok T, Socinski MA, Gervais $\mathrm{R}, \mathrm{Wu} Y$-L, et al: Gefitinib versus docetaxel in previously treated non-small-cell lung cancer (INTEREST): a randomised phase III trial. Lancet 2008;372:1809-1818.

34 Maruyama R, Nishiwaki Y, Tamura T, Yamamoto N, Tsuboi M, Nakagawa K, et al: Phase III study, V-15-32, of gefitinib versus docetaxel in previously treated Japanese patients with non-small-cell lung cancer. J Clin Oncol 2008; 26:4244-4252.

35 Shepherd FA, Rodrigues Pereira J, Ciuleanu T, Tan EH, Hirsh V, Thongprasert S, et al: Erlotinib in previously treated non-smallcell lung cancer. N Engl J Med 2005;353: 123-132.

36 Ciuleanu T, Stelmakh L, Cicenas S, Miliauskas S, Grigorescu AC, Hillenbach C, et al: Efficacy and safety of erlotinib versus chemotherapy in second-line treatment of patients with advanced, non-small-cell lung cancer with poor prognosis (TITAN): a randomised multicentre, open-label, phase 3 study. Lancet Oncol 2012;13:300-308.

37 Chang A, Parikh P, Thongprasert S, Tan EH, Perng R-P, Ganzon D, et al: Gefitinib (IRESSA) in patients of Asian origin with refractory advanced non-small cell lung cancer: subset analysis from the ISEL study. J Thorac Oncol 2006;1:847-855. 
38 Mok TS, Wu Y-L, Thongprasert S, Yang C-H, Chu D-T, Saijo N, et al: Gefitinib or carboplatin-paclitaxel in pulmonary adenocarcinoma. N Engl J Med 2009;361:947-957.

39 Maemondo M, Inoue A, Kobayashi K, Sugawara S, Oizumi S, Isobe $\mathrm{H}$, et al: Gefitinib or chemotherapy for non-small-cell lung cancer with mutated EGFR. N Engl J Med 2010;362: 2380-2388.

40 Mitsudomi T, Morita S, Yatabe Y, Negoro S, Okamoto I, Tsurutani J, et al: Gefitinib versus cisplatin plus docetaxel in patients with nonsmall-cell lung cancer harbouring mutations of the epidermal growth factor receptor (WJTOG3405): an open label, randomised phase 3 trial. Lancet Oncol 2010;11:121-128.

41 Zhou C, Wu Y-L, Chen G, Feng J, Liu X-Q, Wang $C$, et al: Erlotinib versus chemotherapy as first-line treatment for patients with advanced EGFR mutation-positive non-smallcell lung cancer (OPTIMAL, CTONG-0802): a multicentre, open-label, randomised, phase 3 study. Lancet Oncol 2011;12:735-742.

42 Rosell R, Carcereny E, Gervais R, Vergnenegre A, Massuti B, Felip E, et al: Erlotinib versus standard chemotherapy as first-line treatment for European patients with advanced EGFR mutation-positive non-small-cell lung cancer (EURTAC): a multicentre, open-label, randomised phase 3 trial. Lancet Oncol 2012; 13:239-246.

43 Sequist LV, Yang JC-H, Yamamoto N, O’Byrne K, Hirsh V, Mok T, et al: Phase III study of afatinib or cisplatin plus pemetrexed in patients with metastatic lung adenocarcinoma with EGFR mutations. J Clin Oncol 2013;31:3327-3334.

44 Wu Y-L, Zhou C, Hu C-P, Feng J, Lu S, Huang $\mathrm{Y}$, et al: Afatinib versus cisplatin plus gemcitabine for first-line treatment of Asian patients with advanced non-small-cell lung cancer harbouring EGFR mutations (LUX-Lung 6): an open-label, randomised phase 3 trial. Lancet Oncol 2014;15:213-222.
45 Lee SM, Khan I, Upadhyay S, Lewanski C, Falk S, Skailes G, et al: First-line erlotinib in patients with advanced non-small-cell lung cancer unsuitable for chemotherapy (TOPICAL): a double-blind, placebo-controlled, phase 3 trial. Lancet Oncol 2012;13:11611170.

46 Inoue A, Kobayashi K, Usui K, Maemondo M, Okinaga S, Mikami I, et al: First-line gefitinib for patients with advanced non-small-cell lung cancer harboring epidermal growth factor receptor mutations without indication for chemotherapy. J Clin Oncol 2009;27:13941400.

47 Reck M, van Zandwijk N, Gridelli C, Baliko Z Rischin D, Allan S, et al: Erlotinib in advanced non-small cell lung cancer: efficacy and safety findings of the global phase IV Tarceva Lung Cancer Survival Treatment study. J Thorac Oncol 2010;5:1616-1622.

48 Cappuzzo F, Ciuleanu T, Stelmakh L, Cicenas S, Szczésna A, Juhász E, et al: Erlotinib as maintenance treatment in advanced nonsmall-cell lung cancer: a multicentre, randomised, placebo-controlled phase 3 study. Lancet Oncol 2010;11:521-529.

49 Takeda K, Hida T, Sato T, Ando M, Seto T, Satouchi M, et al: Randomized phase III trial of platinum-doublet chemotherapy followed by gefitinib compared with continued platinum-doublet chemotherapy in Japanese patients with advanced non-small-cell lung cancer: results of a west Japan thoracic oncology group trial (WJTOG0203). J Clin Oncol 2010; 28:753-760

50 Zhang L, Ma S, Song X, Han B, Cheng Y, Huang C, et al: Gefitinib versus placebo as maintenance therapy in patients with locally advanced or metastatic non-small-cell lung cancer (INFORM; C-TONG 0804): a multicentre, double-blind randomised phase 3 trial. Lancet Oncol 2012;13:466-475.

51 Louis RA, Rajendranath R, Ganesan P, Sagar TG, Krishnamurthy A: First report of upfront treatment with Gefitinib in comparison with chemotherapy in advanced non-small cell lung cancer patients from south India: analysis of 120 patients. Indian J Med Paediatr Oncol 2012;33:146-154.
52 Ohashi K, Maruvka YE, Michor F, Pao W: Epidermal growth factor receptor tyrosine kinase inhibitor-resistant disease. J Clin Oncol 2013;31:1070-1080.

53 Arcila ME, Oxnard GR, Nafa K, Riely GJ, Solomon SB, Zakowski MF, et al: Rebiopsy of lung cancer patients with acquired resistance to EGFR inhibitors and enhanced detection of the T790M mutation using a locked nucleic acid-based assay. Clin Cancer Res 2011;17: 1169-1180.

54 Sequist LV, Waltman BA, Dias-Santagata D, Digumarthy S, Turke AB, Fidias P, et al: Genotypic and histological evolution of lung cancers acquiring resistance to EGFR inhibitors. Sci Transl Med 2011;3:75ra26.

55 Jänne PA, Yang JC, Kim DW, Planchard D, Ohe Y, Ramalingam SS, et al: AZD9291 in EGFR inhibitor-resistant non-small-cell lung cancer. N Engl J Med 2015;372:1689-1699.

56 Sequist LV, Soria JC, Goldman JW, Wakelee HA, Gadgeel SM, Varga A, et al: Rociletinib in EGFR-mutated non-small-cell lung cancer. N Engl J Med 2015;372:1700-1709.

57 Park K, Tsai CM, Ahn M, Yu CJ, Kim SW, Sriuranpong V, et al: ASPIRATION: Phase II study of continued erlotinib beyond RECIST progression in Asian patients (pts) with epidermal growth factor receptor (EGFR) mutation-positive non-small cell lung cancer (NSCLC). J Clin Oncol 2012;30(suppl; abstr TPS7614).

58 Soria JC, Wu YL, Nakagawa K, Kim SW, Yang JJ, Ahn MJ, et al: Gefitinib plus chemotherapy versus placebo plus chemotherapy in EGFRmutation-positive non-small-cell lung cancer after progression on first-line gefitinib (IMPRESS): a phase 3 randomised trial. Lancet Oncol 2015;16:990-998.

59 Ellison G, Zhu G, Moulis A, Dearden S, Speake G, McCormack R, et al: EGFR mutation testing in lung cancer: a review of available methods and their use for analysis of tumour tissue and cytology samples. J Clin Pathol 2013;66:79-89. 